varying concentrations $(0,3.125-100 \mathrm{ng} / \mathrm{ml})$ of recombinant human MCP-1 (R\&D Systems) was tested using the CytoSelect 96-well cell migration assay (Cell Biolabs, San Diego, CA, USA). All experiments were run a single time with each treatment group run in triplicate. After normalization for cell viability, cell culture results were expressed as fold change from the media only negative control (no CS, no LPS). One-way ANOVA with Bonferroni's post-hoc test and post-hoc linear trend were performed on cell culture results using Graphpad Prism software (La Jolla, CA, USA).

Results: We found that LPS $(1 \mu \mathrm{g} / \mathrm{ml})$ caused a significant rise in MCP-1 release $(p<0.0001)$ from 3T3-L1 adipocytes. CS in physiologically achievable concentrations $(100-200 \mu \mathrm{g} / \mathrm{ml})$ produced a dose dependent reduction $(p<0.01$ at $100 \mu \mathrm{g} / \mathrm{ml}$ and $\mathrm{p}<0.001$ at $200 \mu \mathrm{g} / \mathrm{ml}$ ) of MCP-1 release from 3T3-L1 adipocytes in response to LPS. Recombinant MCP-1 $(25-100 \mathrm{ng} / \mathrm{ml})$ caused a dose dependent increase $(p<0.001$ at $25 \mathrm{ng} / \mathrm{ml}$ and $P<0.0001$ at $100 \mathrm{ng} / \mathrm{ml})$ in cell migration of THP-1 monocytes. CS at the highest test concentration $(200 \mu \mathrm{g} / \mathrm{ml})$ had no effect on MCP-1 mediated THP-1 migration.

Conclusions: Our data demonstrate that CS inhibits the release of MCP-1 from 3T3-L1 adipocytes that have been stimulated with LPS, but has no effect on the chemotactic action of MCP-1 on THP-1 monocytes. Furthermore, our work data strongly suggests that it is the inhibition of MCP-1 release by CS that underlies this effect and not a direct inhibition of the chemotactic action of MCP-1 by CS. Given the importance of MCP-1 over-production in obesity-related metabolic syndromes, inhibiting the release of MCP-1 from adipocytes by CS, and thus blocking the recruitment of macrophages to adipose tissue, could provide a new treatment opportunity for these syndromes.

Disclosure of Interest: None declared

DOI: 10.1136/annrheumdis-2017-eular.2140

\section{THU0045 IL-21 AND IL-22 ARE INVOLVED IN BONE DESTRUCTION IN RHEUMATOID ARTHRITIS PATIENTS}

E. Kuca-Warnawin ${ }^{1}$, W. Kurowska ${ }^{1}$, A. Radzikowska ${ }^{1}$, G. Pracon ${ }^{2}$, T. Burakowski ${ }^{1}, M$. Olszewska ${ }^{3}$, I. Slowinska ${ }^{4}$, I. Sudol-Szopinska ${ }^{2}$ W. Maslinski ${ }^{1} .{ }^{1}$ Department of Pathophysiology and Immunology; ${ }^{2}$ Department of Radiology; ${ }^{3}$ Department of Anesthesiology and Intensive Care; ${ }^{4}$ Department of Rheumoorthopaedic Surgery, National Institute of Geriatrics, Rheumatology, and Rehabilitation, Warsaw, Poland

Background: Inflammatory process in bone marrow (BM) observed on MRI scans of rheumatoid arthritis (RA) patients (called bone marrow oedema) was shown to proceed joint destruction in RA. Our previous studies supported the concept that BM actively participate in the pathogenesis of RA by TLR triggered B cell activity (1), increased number of activated T cells and increased level of proinflammatory cytokines $(2,3)$. Cytokines play a key role in the bone destruction of rheumatoid arthritis.

Objectives: To investigate the levels of IL-21 and IL-22 in RA BM plasma and their association with bone destruction.

Methods: BM samples were obtained from RA and osteoarthritis $(\mathrm{OA})$ patients during total hip replacement surgery. Levels of IL-17AF, IL-21, IL-22, RANKL and cathepsin $\mathrm{K}$ in BM plasma were determined by specific ELISA tests. We analyzed pelvic radiographs of 22 patients with RA admitted to the NIGRR and subjected to total hip replacement. Radiographs were taken a day or two before surgery. In our study we assessed hip joint changes semi-quantitatively with the use of the proposed scoring system including primary RA (juxta-articular osteoporosis, axial joint space narrowing inflammatory cyst presence, bony erosion) and late RA changes (axial migration of the femoral head, femoral head deformation, avascular necrosis of femoral head, femoral head subluxation).

Results: We found increased levels of activated $T$ cell associated cytokines $\mathrm{IL}-21(924.8 \mathrm{pg} / \mathrm{ml}$ vs $688.6 \mathrm{pg} / \mathrm{ml}, \mathrm{p}<0.05)$ and $\mathrm{IL}-22(94.5 \mathrm{pg} / \mathrm{ml}$ vs 65.8 $\mathrm{pg} / \mathrm{ml}, \mathrm{p}<0.05)$ in $\mathrm{BM}$ plasma of RA patients in comparison to osteoarthritis (OA) patients. Interestingly levels of both of these cytokines strongly correlated positively with concentration of osteoclastogenesis/osteoclast activity marker RANKL and cathepsin K. Surprisingly level of IL-17AF did not correlate with RANKL or cathepsin K. Furthermore, concentration of IL-21 was statistically significantly higher in patients with more severe radiologically assessed bone destruction. Median value of concentration of IL-21 in RA patients with small bone destruction was $797.4 \mathrm{pg} / \mathrm{ml}$, with mild bone destruction was $1037.8 \mathrm{pg} / \mathrm{ml}$, with severe bone destruction $(1079.0 \mathrm{pg} / \mathrm{ml})$.

Conclusions: Our results show an association between BM plasma levels of IL-21 and IL-22 and bone destruction, supporting the hypothesis that IL-21 and IL-22 are important pathogenic factors of this disease. Therapy targeting IL-21 and IL-22 may be of value in preventing bone erosions in patients with RA.

References:

[1] W Rudnicka et al.: Eur J Immunol 2009; 12.

[2] E Kuca-Warnawin et al.: Ann Rheum Dis Jan;70(1):227-33.

[3] E Kuca-Warnawin et al.: Reumatologia 2016;54(2):51-3.

Acknowledgements: This work was sponsored by grant No UMO2011/03/B/NZ6/05035 from National Science Centre, Poland.

Disclosure of Interest: None declared

DOI: 10.1136/annrheumdis-2017-eular.5701

\section{THU0046 CALCIUM PYROPHOSPHATE AND MONOSODIUM URATE CRYSTAL-INDUCED PROSTAGLANDIN E2 PRODUCTION INVOLVES NF-KB ACTIVATION AND ROS PRODUCTION, INDEPENDENTLY OF INTERLEUKIN-1BETA AXIS}

F. Renaudin ${ }^{1,2}$, L. Campillo-Gimenez ${ }^{1}$, C. Combes ${ }^{3}$, M. Gosset ${ }^{4}$, M. Cohen-Solal ${ }^{1,5}$, F. Lioté ${ }^{1,5}$, H.-K. Ea ${ }^{1,5} .{ }^{1}$ UMR1132, Bioscar, Inserm ${ }^{2}$ University Paris Diderot, Paris; ${ }^{3}$ CIRIMAT, Université de Toulouse, INPT, UPS, CNRS, Ensiacet, Toulouse; ${ }^{4}$ EA 2496, UFR Odontologie, Paris Descartes, Montrouge; ${ }^{5}$ Service de Rhumatologie, centre Viggo Petersen, AP-HP, hôpital Lariboisière, Paris, France

Background: Monoclinic and triclinic calcium pyrophosphate dihydrated (mCPPD and tCPPD) and monosodium urate (MSU) crystals are responsible in human for relapsing acute arthritis. CPP and MSU crystal-triggered inflammation depends on several inflammatory mediators including interleukin (IL)-1 $\beta$ and prostaglandin (Pg) E2. IL-1 $\beta$ production is governed by NF-kB, NLRP3 inflammasome and caspase-1 activation. $\mathrm{PgE}_{2}$ derives from arachidonic acid (AA) synthesis, which is regulated by cytosolic phospholipase $\mathrm{A} 2\left(\mathrm{CPLA}_{2}\right)$, and cyclooxygenase-(COX) 2 activation. CPP crystal-induced IL-1 $\beta$ production is well documented, but CPP crystal-induced PgE2 production remains unclear.

Objectives: To evaluate how $\mathrm{CPP}$ crystals induce $\mathrm{PgE}_{2}$ production and the role of IL- $1 \beta$ in this process.

Methods: Synthetic and pyrogen-free m-CPPD, t-CPPD and MSU crystals were used to stimulate human monocyte cell line (THP-1 cells) and primary bone marrow-derived macrophages (BMDM) of wild type (wt) and NLRP3 inflammasome deficient $\left(\mathrm{nlrp3}^{-1-}\right)$ mice. Pharmacological inhibitors were used to assess the role of oxidative stress (N-acetyl-L-cysteine, NAC) and NF-KB pathway (Bay-117085). $\mathrm{PgE}_{2}$ and IL-1 $\beta$ production were quantified by ELISA, gene expression by qRT-PCR, $\mathrm{CPLA}_{2}$ by immunoblot. NF-kB activation was assessed in THP-1 cells containing a reporter gene under control of NF-кB p65 promotor. In vivo, CPP crystal-induced PgE2 production was evaluated in the air pouch model in the presence or not of NF-KB inhibitor or NAC.

Results: In vitro, $\mathrm{m}$ - and $\mathrm{t}-\mathrm{CPPD}$ and MSU crystals rapidly induced the production of $\mathrm{PgE}_{2}$ and IL-1 $\beta$ by THP-1 cells and BMDM. PgE 2 production was associated with $\mathrm{CPLA}$ and NF-kB activation along with increased expression of COX-2 (20 fold) and its receptor EP2 and EP4 genes. While CPP crystal-induced IL-1 $\beta$ production was abolished in THP-1 cells by treatment with caspase-1 inhibitor and in $\mathrm{nlrp3}^{-{ }^{-}}$BMDM, CPP crystal-induced $\mathrm{PgE}_{2}$ was not modified suggesting IL-1 $\beta$ - and NLRP3-independent pathways. Interestingly, CPP crystal-induced $\mathrm{PgE}_{2}$ production was completely abrogated by NF-KB inhibitor treatment and significantly decreased by the antioxidant NAC; in both case, COX-2 gene expression was dramatically inhibited. In vivo, treatment with NAC or Bay strongly inhibited IL- $1 \beta$ and $\mathrm{PgE}_{2}$ production and cellular infiltrate induced by CPP crystals. Conclusions: $\mathrm{PgE}_{2}$ production mediated by $\mathrm{CPP}$ and MSU crystals is activated by NF- $\mathrm{KB}$ signaling, independently of NLRP3/IL- $1 \beta$ production axis. Moreover, ROS production, known as a NLRP3 activator in response to CPPD or MSU crystals, is also involved in the regulation of $\mathrm{PgE}_{2}$ production. The relations between these different pathways are under investigation.

Disclosure of Interest: None declared

DOI: 10.1136/annrheumdis-2017-eular.5505

\section{THU0047 RESVERATROL AND ITS PRECURSOR POLYDATIN INHIBIT CRYSTAL-INDUCED INFLAMMATION IN VITRO BY DECREASING OXIDATIVE STRESS AND IL-1BETA ACTIVATION PATHWAY}

Y. Zamudio-Cuevas ${ }^{1}$, F. Oliviero ${ }^{2}$, E. Belluzzi ${ }^{2}$, A. Scanu ${ }^{2}$, L. Andretto ${ }^{2}$ P. Galozzi ${ }^{2}$, M. Favero ${ }^{2}$, R. Ramonda ${ }^{2}$, P. Spinella ${ }^{3}$, G. Ravagnan ${ }^{4}$, A. Lopez-Reyes ${ }^{5}$, L. Punzi ${ }^{2} .{ }^{1}$ Instituto Nacional de Rehabilitación, Mexico City, Mexico; ${ }^{2}$ Rheumatology Unit, University of Padova; ${ }^{3}$ Clinica Nutrition Unit, University of Padova, Padova; ${ }^{4}$ Istituto di Farmacologia Traslazionale (IFT) CNR, Roma, Italy; ${ }^{5}$ Instituto Nacional de Rehabilitación, Mexico City, Mexico

Background: Resveratol (RES) and its natural precursor polydatin (PD) are polyphenol compounds that display a broad variety of beneficial effects including anti-apoptotic and anti-inflammatory properties.

Objectives: This study aimed to investigate the role of RES and PD in the inflammatory process induced by monosodium urate (MSU) and calcium pyrophosphate (CPP) crystals in vitro. Their effect was evaluated though IL-1 $\beta$, NLRP3 inflammasome, reactive oxygen species (ROS), nitric oxide (NO) and the phagocytosis index assessment.

Methods: A monocytic cell line (THP-1) was primed for 3 hours with phorbol myristate acetate $(P M A)(100 \mathrm{ng} / \mathrm{ml})$ and stimulated with synthetic MSU $(0.05 \mathrm{mg} / \mathrm{ml})$ and CPP $(0.025 \mathrm{mg} / \mathrm{ml})$ crystals. RES and PD were added to cultures at, respectively, $100 \mu \mathrm{M}$ and $200 \mu \mathrm{M}$. Experiments were carried out either adding RES and PD along with crystals, or pretreating cells ( $2 \mathrm{hs})$ with polyphenols and removing them before crystal stimulation. IL-1 $\beta$ were evaluated in cell supernatants and at intracellular level by ELISA assay. IL-1 $\beta$ and NLRP3 expression was assessed by RT-PCR. Reactive oxygen species (ROS) and NO were measured by cytometric analysis using fluorogenic probes (CellROX Deep Red Reagent and DAF-FM, respectively). Crystal phagocytosis index was calculated at different time points using polarized light microscopy.

Results: RES and PD inhibited IL-1b induced by crystals both at extracellular 